\title{
ECONOMIC ANALYSIS OF APPLICATION OF DIFFERENT DRIVE TRAINS IN VEHICLES
}

Ivan Grujić ${ }^{1}$, Aleksandar Davinić, Nadica Stojanović, Dragan Taranović, Radivoje Pešić

UDC: $629.331 .1 ; 629.3 .026 .12 ; 330.123 .72$

DOI: $10.24874 / m v m .2017 .43 .02 .03$

\begin{abstract}
Vehicles are considered to be the biggest polluters of the environment. An alternative to conventional vehicles are hybrid and electric vehicles. Despite the good qualities of these vehicles, they can rarely be seen on the roads. In this paper, economic analysis is performed in order to determine cost effectiveness of the application of these types of vehicles. A comparison between the costs of owning a hybrid, conventional and electric vehicle is considered, in order to determine whether the costs have the greatest impact on the purchase of these vehicles. The costs included: price of a new vehicle, fuel price per $\mathrm{km}$ and maintenance price per $\mathrm{km}$. The performed analysis shows that hybrid and electric vehicles do not have better economic indicators than vehicles with IC engines.
\end{abstract}

KEY WORDS: hybrid, conventional, electric, vehicles, costs, analysis

\section{EKONOMSKA ANALIZA PRIMENE RAZLIČITIH POGONA U VOZILIMA}

REZIME: Vozila se smatraju najvećim zagađivačima okoline. Alternativa konvencionalnim vozilima su hibridna i električna vozila. Uprkos dobrim osobinama ovih vozila, retko se mogu videti na putevima. U ovom radu, izvršena je ekonomska analiza kako bi se utvrdila isplativost primene ovih tipova vozila. Urađeno je poređenje između troškova posedovanja hibridnog, konvencionalnog i električnog vozila, u cilju utvrđivanja da li troškovi imaju najveći uticaj na kupovinu ovakvih vozila. U troškove su uključeni cena novog vozila, cena goriva po $\mathrm{km}$ i cena održavanja po $\mathrm{km}$. Izvršena analiza pokazala je da hibridna i električna vozila nemaju bolje ekonomske pokazatelje od vozila sa motorom SUS.

KLJUČNE REČI: hibridno, konvencionalno, električno, vozila, troškovi, analiza

${ }^{1}$ Received January 2017, Accepted May 2017, Published On Line June 2017 
Intentionally blank 


\title{
ECONOMIC ANALYSIS OF APPLICATION OF DIFFERENT DRIVE TRAINS IN VEHICLES
}

\author{
Ivan Grujić ${ }^{1}$, Aleksandar Davinić ${ }^{2}$, Nadica Stojanović ${ }^{3}$, Dragan Taranović ${ }^{4}$, \\ Radivoje Pešić 5
}

\section{INTRODUCTION}

The development of combustion engines, especially vehicle engines, is one of the greatest achievements in technology. More precisely, a life without a vehicle is impossible today. This is because vehicles have a major role in everyday life of modern society. In addition, vehicle production has a big influence on the world economy. It is best explained by an increasing trend of numbers of light duty vehicles in the world, shown in Figure 1. The everyday increase of number of vehicles, unfortunately, has a negative effect, such as air pollution and higher fuel consumption. This kind of problem created a need to produce vehicles that are less polluting and have a lower fuel consumption. One of the best choices of vehicles is a hybrid electric vehicle. Despite their good qualities, the hybrid vehicles are rarely seen on the road [1]. Why does this happen? One of possible answers is the existence of opinion that these vehicles are expensive to own.

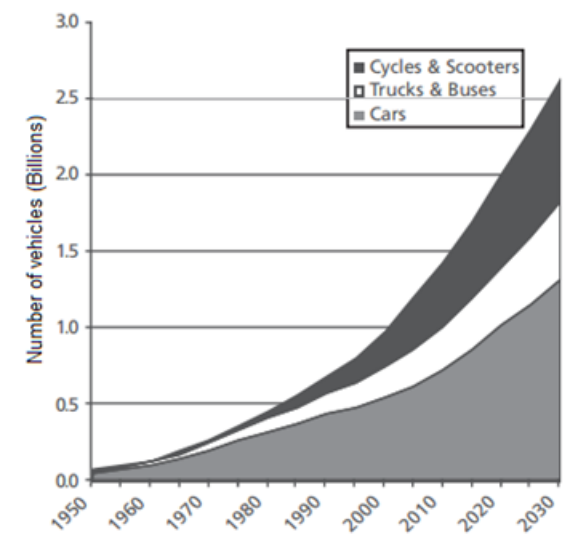

Figure 1 Global growth of vehicles [2]

\footnotetext{
${ }^{1}$ Ivan Grujić, M.Sc., assist., University of Kragujevac, Faculty of Engineering, 6 Sestre Janjić Str., 34000 Kragujevac, Serbia, ivan.grujic@kg.ac.rs

${ }^{2}$ Aleksandar Davinić, Ph. D., assist. prof., University of Kragujevac, Faculty of Engineering, 6 Sestre Janjić Str., 34000 Kragujevac, Serbia, davinic@kg.ac.rs

${ }^{3}$ Nadica Stojanović, M.Sc., assist., University of Kragujevac, Faculty of Engineering, 6 Sestre Janjić Str., 34000 Kragujevac, Serbia, nadica.stojanovic@kg.ac.rs

${ }^{4}$ Dragan Taranović, Ph. D., assist. prof., University of Kragujevac, Faculty of Engineering, 6 Sestre Janjić Str., 34000 Kragujevac, Serbia, tara@kg.ac.rs

${ }^{5}$ Radivoje Pešić, Ph. D., prof., University of Kragujevac, Faculty of Engineering, 6 Sestre Janjić Str., 34000 Kragujevac, Serbia, pesicr@kg.ac.rs
} 
The main purpose of this paper is to conduct the cost-effectiveness analysis of buying and owning vehicles with different drive trains. In order to perform the costeffectiveness analysis, data on costs of buying and owning vehicles with different drive trains are necessary.

\section{RESEARCH METHOD AND MATERIALS}

The best method for this type of the analysis is a statistical method. Data needed for statistical analysis in this paper are taken from [3]. The basic idea of the research is to compare the costs of ownership of hybrid, conventional and electric vehicles. Six vehicles were used in research, two for each type of drivetrain. The first group of vehicles used in analysis consists of: Toyota Yaris 1.3 (conventional), Toyota Prius 1.5 (hybrid) and Nissan Leaf (electric), Figure 2. The second group contains more luxury vehicles then vehicles from the first group. Vehicles from the second group are: Nissan Qashqai 2.0 (conventional), Toyota Prius 1.8 (hybrid) and Holden Volt (electric), Figure 3.

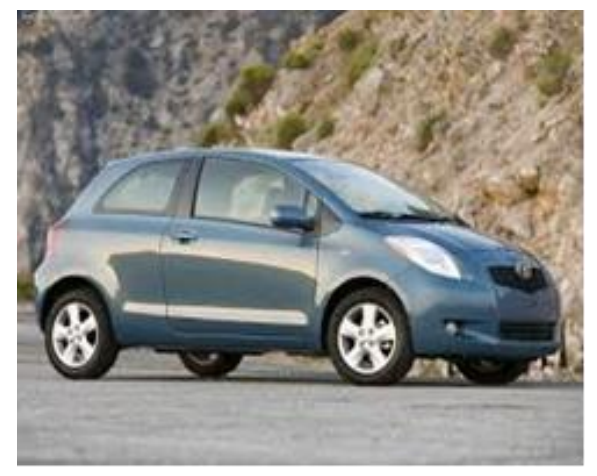

a) Toyota Yaris 1.3

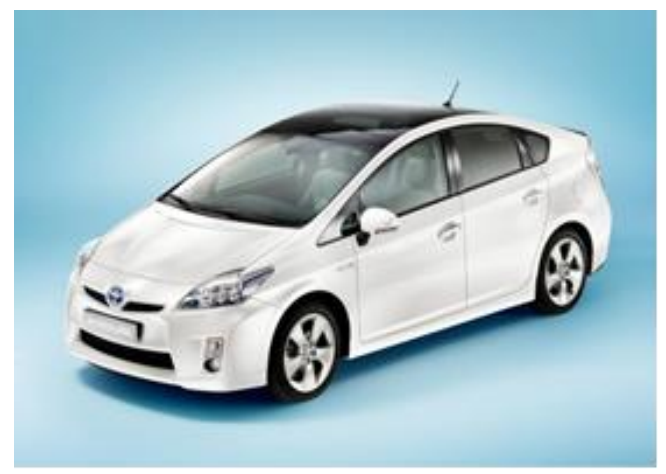

b) Toyota Prius 1.5

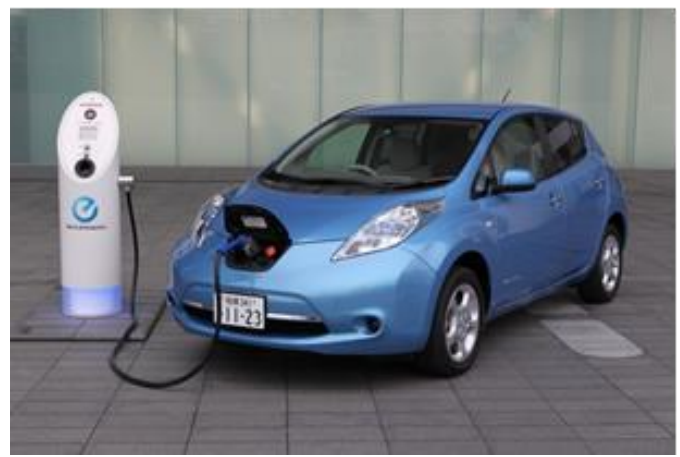

c) Nissan Leaf

Figure 2 Vehicles used for research [4, 5, 6] 


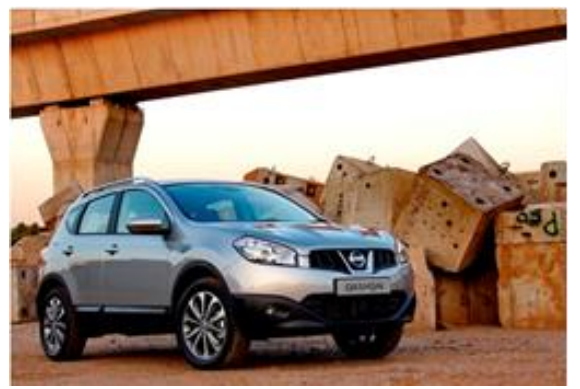

a) Nissan Qashqai

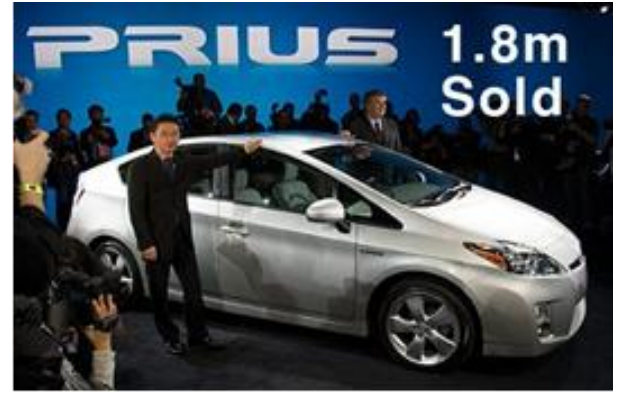

b) Toyota Prius 1.8

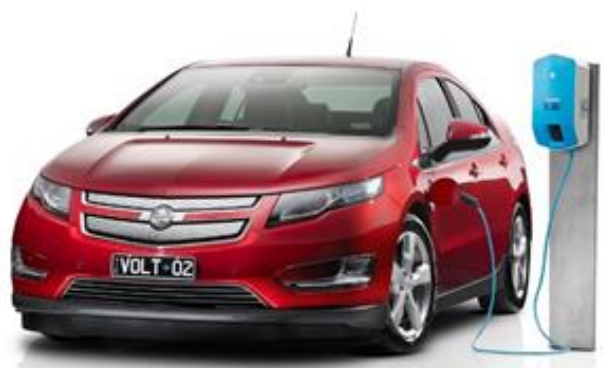

c) Holden Volt

Figure 3 Vehicles used for research [7, 8, 9]

Table 1 Price values in \$ [3]

\begin{tabular}{|c|c|c|c|}
\cline { 2 - 4 } \multicolumn{1}{c|}{} & $\begin{array}{c}\text { Price of a new } \\
\text { vehicle }(P N V)\end{array}$ & $\begin{array}{c}\text { Fuel price } \\
\text { per km }(F P)\end{array}$ & $\begin{array}{c}\text { Maintenance price } \\
\text { per km }(M P)\end{array}$ \\
\hline Toyota Yaris 1.3 & 16,490 & 0.0819 & 0.0807 \\
\hline Toyota Prius 1.5 & 22,990 & 0.055 & 0.0945 \\
\hline Nissan Leaf & 34,200 & 0.0483 & 0.0709 \\
\hline Nissan Qashqai 2.0 & 28,490 & 0.0897 & 0.0634 \\
\hline Toyota Prius 1.8 & 32,490 & 0.055 & 0.0967 \\
\hline Holden Volt & 59,990 & 0.0546 & 0.0574 \\
\hline
\end{tabular}

Based on prices given in Table 1, the analysis of ownership costs for 75,000 km $\left(P_{75000}\right)$ and $150,000 \mathrm{~km}\left(P_{150000}\right)$ travelled by vehicle is performed and difference between these values $(P D)$ is calculated:

$P_{75000}=P N V+(F P+M P) \cdot 75000$ 
$P_{150000}=P N V+(F P+M P) \cdot 150000$

$P D=P_{150000}-P_{75000}$

In addition, according to data from Table 1, analysis of ownership costs per year (PPY) is conducted, assuming that the vehicle travels $50,000 \mathrm{~km}$ per year. For this calculation, the next equation is used.

$P P Y=P N V+(F P+M P) \cdot 50000 \cdot N Y$

\section{RESULTS AND DISCUSSION}

By using data from Table 1, and equations (1) to (3), the following data are obtained and presented in Table 2 .

Table 2 Costs of ownership for 75,000 km and 150,000 km and difference of costs in \$

\begin{tabular}{|c|c|c|c|}
\cline { 2 - 4 } \multicolumn{1}{c|}{} & $P_{75000}$ & $P_{150000}$ & $P D$ \\
\hline Toyota Yaris 1.3 & 28,685 & 40,880 & 12,195 \\
\hline Toyota Prius 1.5 & $34,202.5$ & 45,415 & $11,212.5$ \\
\hline Nissan Leaf & 43,140 & 52,080 & 8,940 \\
\hline Nissan Qashqai 2.0 & $39,972.5$ & 51,455 & $11,482.5$ \\
\hline Toyota Prius 1.8 & $43,867.5$ & 55,245 & $11,377.5$ \\
\hline Holden Volt & 68,390 & 76,790 & 8,400 \\
\hline
\end{tabular}

Data from Table 2 can be better analyses observing the Figure 4 (for the first group of vehicles) and Figure 5 (for the second group of vehicles), where ownership costs after $75,000 \mathrm{~km}$ travelled are presented.

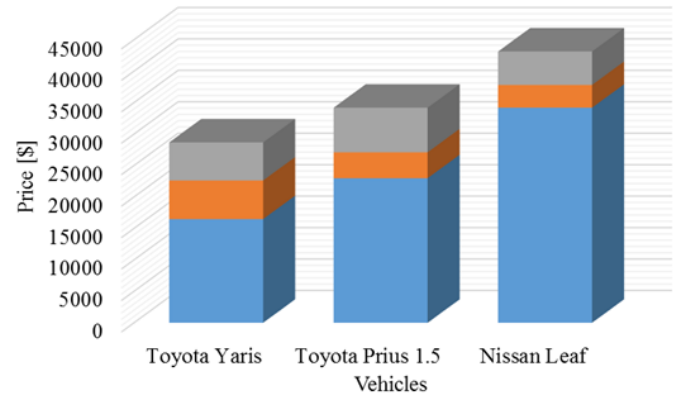

Figure 4 Costs of ownership (the first group of vehicles) for 75,000 km travelled 


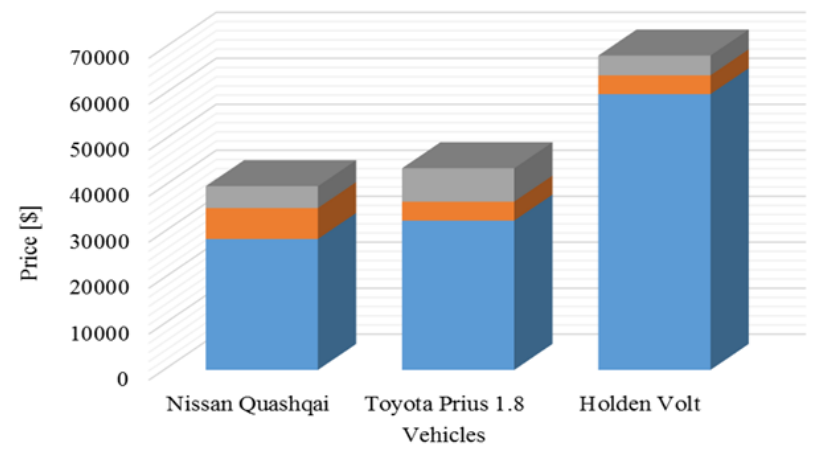

Figure 5 Costs of ownership (the second group of vehicles) for 75,000 km travelled

By analysis of data from Figures 4 and 5, it can be seen that the most expensive vehicle to own is the electric vehicle. The reason is a high price for a new vehicle. Hybrid vehicle is the most expensive to maintain because of the two types of drivetrain. In addition, it can be seen that the hybrid vehicle is still more expensive to own after $75,000 \mathrm{~km}$ travelled than conventional vehicle. Also, from Table 2, it can be seen that after $150,000 \mathrm{~km}$ travelled, the vehicle with conventional drive train is still cheaper than vehicles with other types of drive trains.

In addition, calculations were performed in order to see how many kilometres the hybrid or electric vehicle needs to travel to be less expensive than vehicle with conventional drive train. Boundaries are set at vehicles traveling $50,000 \mathrm{~km}$ per year. Analysis is performed for a period of 10 years. Results are given in Tables 3 and 4 and Figures 6 and 7 .

Table 3 Costs of ownership through years in \$ (the first group of vehicles)

\begin{tabular}{|c|c|c|c|c|c|c|c|}
\hline $\begin{array}{c}\text { Distance } \\
\text { travelled } \\
{[\mathrm{km}]}\end{array}$ & $\begin{array}{c}\text { Toyota } \\
\text { Yaris }\end{array}$ & $\begin{array}{c}\text { Toyota } \\
\text { Prius 1.5 }\end{array}$ & $\begin{array}{c}\text { Nissan } \\
\text { Leaf }\end{array}$ & $\begin{array}{c}\text { Time } \\
\text { [years] }\end{array}$ & $\begin{array}{c}\text { Toyota } \\
\text { Yaris }\end{array}$ & $\begin{array}{c}\text { Toyota } \\
\text { Prius 1.3 }\end{array}$ & $\begin{array}{c}\text { Nissan } \\
\text { Leaf }\end{array}$ \\
\hline $\begin{array}{c}\text { Vehicle } \\
\text { price }\end{array}$ & 16490 & 22990 & 34200 & & & & \\
\hline 1 & 0.1626 & 0.1495 & 0.1192 & & & & \\
\hline 50,000 & 8,130 & 7,475 & 5,960 & 1 & 24,620 & 30,465 & 40,160 \\
\hline 100,000 & 16,260 & 14,950 & 11,920 & 2 & 32,750 & 37,940 & 46,120 \\
\hline 150,000 & 24,390 & 22,425 & 17,880 & 3 & 40,880 & 45,415 & 52,080 \\
\hline 200,000 & 32,520 & 29,900 & 23,840 & 4 & 49,010 & 52,890 & 58,040 \\
\hline 250,000 & 40,650 & 37,375 & 29,800 & 5 & 57,140 & 60,365 & 64,000 \\
\hline 300,000 & 48,780 & 44,850 & 35,760 & 6 & 65,270 & 67,840 & 69,960 \\
\hline 350,000 & 56,910 & 52,325 & 41,720 & 7 & 73,400 & 75,315 & 75,920 \\
\hline 400,000 & 65,040 & 59,800 & 47,680 & 8 & 81,530 & 82,790 & 81,880 \\
\hline 450,000 & 73,170 & 67,275 & 53,640 & 9 & 89,660 & 90,265 & 87,840 \\
\hline 500,000 & 81,300 & 74,750 & 59,600 & 10 & 97,790 & 97,740 & 93,800 \\
\hline
\end{tabular}


Table 4 Costs of ownership through years in \$ (the second group of vehicles)

\begin{tabular}{|c|c|c|c|c|c|c|c|}
\hline $\begin{array}{c}\text { Distance } \\
\text { travelled } \\
{[\mathrm{km}]}\end{array}$ & $\begin{array}{c}\text { Nissan } \\
\text { Qashqai } \\
2.0\end{array}$ & $\begin{array}{c}\text { Toyota } \\
\text { Prius 1.8 }\end{array}$ & $\begin{array}{c}\text { Holden } \\
\text { Volt }\end{array}$ & $\begin{array}{c}\text { Time } \\
\text { [years }]\end{array}$ & $\begin{array}{c}\text { Nissan } \\
\text { Qashqai } \\
2.0\end{array}$ & $\begin{array}{c}\text { Toyota } \\
\text { Prius } 1.8\end{array}$ & $\begin{array}{c}\text { Holden } \\
\text { Volt }\end{array}$ \\
\hline $\begin{array}{c}\text { Vehicle } \\
\text { price }\end{array}$ & 28490 & 32490 & 59990 & & & & \\
\hline 1 & 0.1531 & 0.1517 & 0.112 & & & & \\
\hline 50,000 & 7,655 & 7,585 & 5,600 & 1 & 36,145 & 40,075 & 65,590 \\
\hline 100,000 & 15,310 & 15,170 & 11,200 & 2 & 43,800 & 47,660 & 71,190 \\
\hline 150,000 & 22,965 & 22,755 & 16,800 & 3 & 51,455 & 55,245 & 76,790 \\
\hline 200,000 & 30,620 & 30,340 & 22,400 & 4 & 59,110 & 62,830 & 82,390 \\
\hline 250,000 & 38,275 & 37,925 & 28,000 & 5 & 66,765 & 70,415 & 87,990 \\
\hline 300,000 & 45,930 & 45,510 & 33,600 & 6 & 74,420 & 78,000 & 93,590 \\
\hline 350,000 & 53,585 & 53,095 & 39,200 & 7 & 82,075 & 85,585 & 99,190 \\
\hline 400,000 & 61,240 & 60,680 & 44,800 & 8 & 89,730 & 93,170 & 104,790 \\
\hline 450,000 & 68,895 & 68,265 & 50,400 & 9 & 97,385 & 100,755 & 110,390 \\
\hline 500,000 & 76,550 & 75,850 & 56,000 & 10 & 105,040 & 108,340 & 115,990 \\
\hline
\end{tabular}

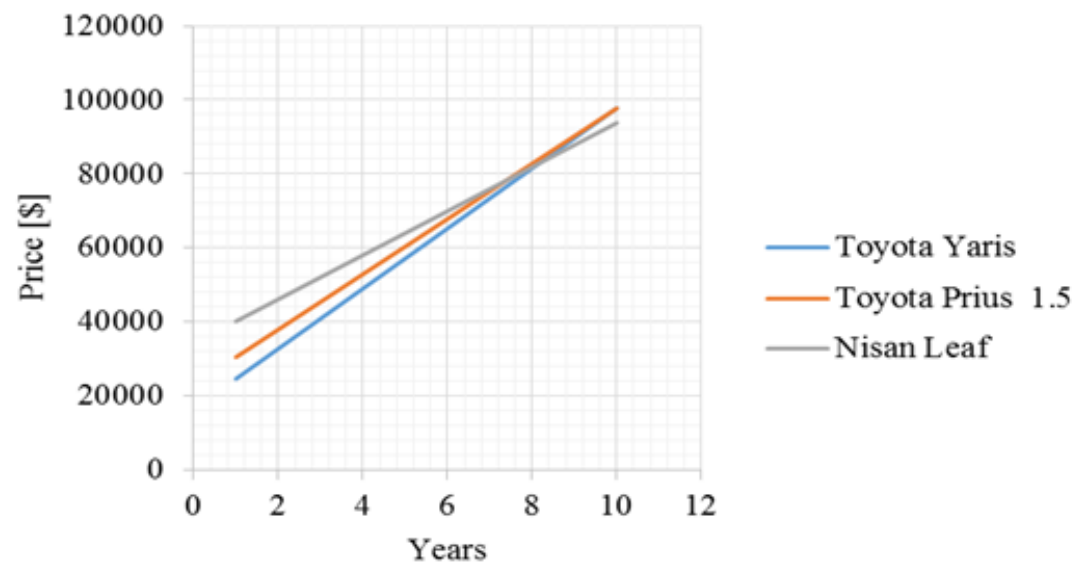

Figure 6 Costs of ownership through years (the first group of vehicles) 


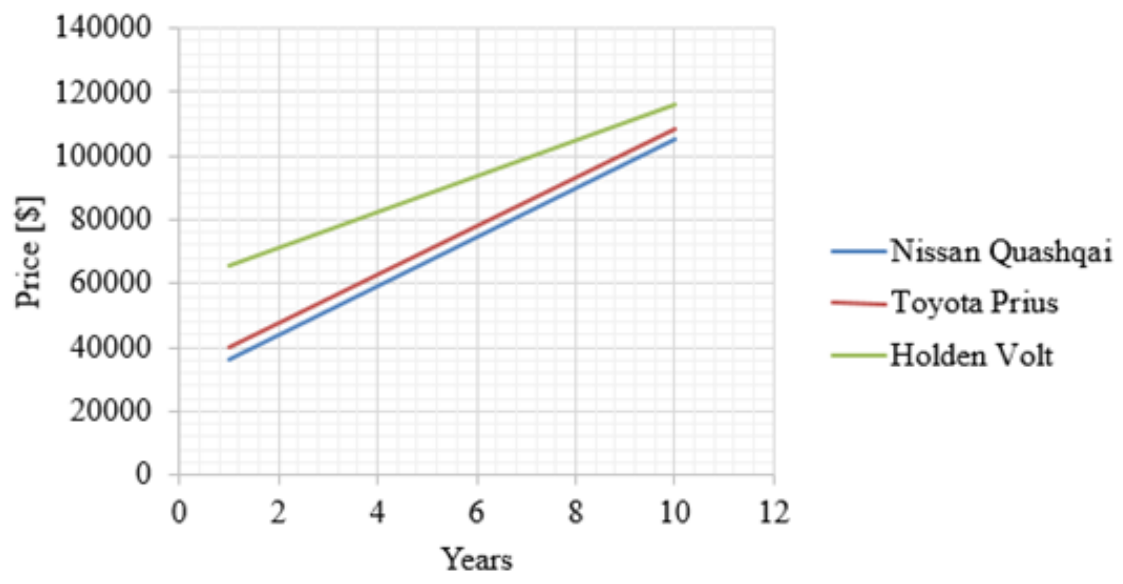

Figure 7 Costs of ownership through years (the second group of vehicles)

By analysis of Figure 6, it can be seen that the hybrid and electric vehicles have more cost effectiveness after 7 years, but if we take into account that vehicle travels over $350,000 \mathrm{~km}$ during this time, that is not good. Figure 7 shows that the vehicle with conventional drive train is more cost-effective even after 10 years.

\section{CONCLUSIONS}

Eclectic and hybrid vehicles are not something new, but strict laws have begun to impose their re-use. Despite the good qualities of these vehicles, they are rarely seen on the road. The main reasons are the costs of ownership. Based on performed analyses, these types of vehicles do not have better economic indicators than conventional vehicles. In one case (the first group of vehicles) these types of vehicles have better economic indicators after $350,000 \mathrm{~km}$ travelled, but this is a very big number. On the other hand, the hybrid and electric vehicles are friendlier to environment. There is a need to motivate people in some way to buy vehicles with these types of drive trains. The good way to achieve this is for states to give some benefits for citizens that are driving these types of vehicles, one of which may be the lower taxes for hybrid vehicles.

\section{ACKNOWLEDGMENT}

This paper was realized within the project "The research of vehicle safety as part of a cybernetic system: Driver-Vehicle-Environment", ref. no. 35041, funded by Ministry of Education, Science and Technological Development of the Republic of Serbia.

\section{REFERENCES}

[1] Carlsson, F., Johansson-Stenman, O.: "Costs and Benefits of Electric Vehicles", Journal of Transport Economics and Policy, Vol. 37, 2003, pp. 1-28.

[2] Sperling, D., and Gordon, D.: "Two Billion Cars: Driving Toward Sustainability". Oxford University Press, 2009.

[3] RACQ, Available from: http://www.racq.com.au/cars-and-driving/cars/owning-andmaintaining-a-car/car-running-costs, Accessed on 28.05.2016. 
[4] PrettyCars, Available from: http://pretty-cars.com/gallery/toyota-yaris-1.3.html, Accessed on 29.05.2016.

[5] PicAutos, Available from: http://www.picautos.com/3576-toyota-prius-hybrid15.html, Accessed on 29.05.2016.

[6] ExtremeTech, Available from: http://www.extremetech.com/extreme/136894-willhigh-mileage-Nisan-leafs-need-costly-battery-replacements-soon, Accessed on 29.05.2016.

[7] SAcarfan, Available from: http://www.sacarfan.co.za/2010/11/road-test-Nisanqashqai-2-0-acenta-cvt/, Accessed on 29.05.2016.

[8] Treehugger, Available from: http://www.treehugger.com/cars/a-decade-of-prius-18million-sold-half-in-the-us.html, Accessed on 29.05.2016.

[9] Treehugger, Available from: http://www.carsguide.com.au/car-news/holden-volt-setto-be-recalled-31335, Accessed on 29.05.2016. 